\title{
PENERAPAN METODE BERMAIN PUZZLE STICK ES KRIM ANAK USIA DINI PADA KELOMPOK B UNTUK MENINGKATKAN KEMAMPUAN BERPIKIR SIMBOLIK
}

\author{
Mimik Kurniawati ${ }^{1}$, Nanin Tresnawaty $^{2}$, Euis Eti Rohaeti ${ }^{3}$, Lenny Nuraeni ${ }^{4}$ \\ ${ }^{1}$ Institut Keguruan dan Ilmu Pendidikan (IKIP) Siliwangi \\ ${ }^{2}$ Institut Keguruan dan Ilmu Pendidikan (IKIP) Siliwangi \\ ${ }^{3}$ Institut Keguruan dan Ilmu Pendidikan (IKIP) Siliwangi \\ ${ }^{4}$ Institut Keguruan dan Ilmu Pendidikan (IKIP) Siliwangi \\ ㅌk kurniawatimimik79@gmail.com, ${ }^{2}$ tresnawatynanin@gmail.com, ${ }^{3}$ e2rht@yahoo.com, \\ ${ }^{4}$ lennynuraeni86@ikipsiliwangi.ac.id
}

\begin{abstract}
This research is based on field findings about the learning process in improving children's symbolic thinking skills carried out without the use of varied educational play tools. Playing an ice cream stick puzzle is a new method that is applied to make it easier for children to improve their symbolic thinking skills. This research uses quasi experiment method. Using the method of playing ice cream puzzle sticks, children tend to be more enthusiastic, interested, and more excited when participating in learning. The development of the symbolic thinking ability of children in kindergarten Sandy Putra Dayeuh Kolot after learning the method of playing the Ice Cream Stick puzzle improved better than before using the ice cream puzzle stick. This can be seen from the results of the study before being given 27.58 treatments and after being given treatment increased to 29.25 .
\end{abstract}

Keywords: Symbolic Thinking, Ice Cream Stick Puzzle, Early Childhood

\begin{abstract}
ABSTRAK
Penelitian ini didasari oleh temuan dilapangan tentang proses pembelajaran dalam meningkatkan kemampuan berpikir simbolik anak dilakukan tanpa menggunakan alat permainan edukatif yang bervariasi. Bermain puzzle stick es krim adalah metode baru yang diterapkan untuk memudahkan anak dalam meningkatkan kemampuan berpikir simbolik. Penelitian ini menggunakan metode quasi eksperiment. Menggunakan metode bermain puzzle stick es krim anak cenderung lebih antusias, tertarik, dan lebih bersemangat pada saat mengikuti pembelajaran. Perkembangan kemampuan berpikir simbolik anak di TK Sandy Putra Dayeuh Kolot setelah mengenal metode bermain puzzle Stick Es Krim menjadi meningkat lebih baik dari sebelum menggunakan puzzle stick es krim tersebut. Hal ini terlihat dari hasil penelitian sebelum diberikan perlakuan 27.58 dan sesudah diberikan perlakuan meningkat menjadi 29.25.
\end{abstract}

Kata Kunci: Berpikir Simbolik, Puzzle Stick Es Krim, Anak Usia Dini

\section{PENDAHULUAN}

Pendidikan bagi anak usia dini merupakan pendidikan yang tidak bisa terlepas dari kegiatan bermain. Apapun aktivitas belajar anak selalu dilakukan dengan bermain. Bagi anak usia dini bermain sudah menjadi salah satu kebutuhan pokok yang wajib dipenuhi. Dengan terpenuhinya kebutuhan bermain secara tidak langsung akan 


\section{JURNAL GERIA}

ISSN : XXXX-XXXX (Print) XXXX-XXXX (Online)

Vol.1 | No.1 | Januari 2018

berpengaruh pada pertumbuhan dan perkembangan anak. Di samping itu, dari berbagai hasil penelitian menunjukkan bahwa kegiatan bermain merupakan cara belajar anak-anak yang paling efektif. Hal ini dibuktikan dengan adanya ungkapan "bermain sambil belajar", maksudnya dengan bermain sesungguhnya anak sedang melakukan pembelajaran, baik itu fisik motorik, logika-matematika, bahasa, sosial emosional, kreativitas, maupun seni (Fadlillah, 2017: 1).

Sebagaimana yang dikemukakan Havighurst dalam (Latif, Zukhairina, Zubaidah 2016: 22) yang menyatakan bahwa perkembangan pada satu tahap perkembangan akan menentukan bagi perkembangan selanjutnya.

Sesuai dengan Peraturan Menteri Pendidikan dan Kebudayaan Republik Indonesia No 137 Tahun 2014 salah satu aspek yang harus dikembangkan yaitu aspek perkembangan kognitif dan pemecahan masalah. Anak usia 5-6 tahun seharusnya sudah mampu menyelesaikan masalah sederhana sebagaimana telah diatur dalam Peraturan Menteri Pendidikan dan Kebudayaan Republik Indonesia No 137 Tahun 2014 Tentang Standar Nasional Pendidikan Anak Usia Dini.

Perkembangan

kognitif merupakan dasar bagi kemampuan anak untuk berpikir, berkreativitas dan berkarya. Kognitif mempunyai peranan penting bagi keberhasilan anak dalam belajar karena sebagian besar aktivitas belajar selalu berhubungan dengan masalah mengingat dan berpikir. Kemampuan berpikir anak dapat dilihat saat anak dapat memecahkan masalahmasalah sederhana yang dihadapi, anak mengetahui benda, bentuk dan sebab akibat yang terjadi pada dirinya, anak usia dini mampu membuat karya-karya baru sesuai dengan pengetahuannya.
Salah satu perkembangan kognitif bagi anak usia dini adalah kemampuan berpikir simbolik, di antaranya kemampuan menunjukkan lambang bilangan, mengurutkan lambang bilangan, menyebutkan huruf vokal dan huruf konsonan, menunjukkan lambang huruf vokal dan lambang huruf konsonan, menyusun lambang huruf menjadi kata.

Dalam kegiatan pembelajaran anak usia dini, alat permainan edukatif memiliki peranan cukup penting. Karena melalui alat permainan edukatif ini kegiatan pembelajaran akan berlangsung menarik, kreatif dan menyenangkan, sehingga dapat mempermudah tercapainya tujuan pembelajaran. Selain itu, dengan alat permainan edukatif ini anak belajar tapi terasa bermain. Maksudnya, meskipun aktivitas yang dilakukan anak adalah bermain, namun dalam bermain itu sesungguhnya anak telah belajar (Fadlillah, 2017: 61).

Mengingat begitu pentingnya alat permainan bagi pendidikan anak usia dini. Kenyataan yang terjadi saat ini terdapat beberapa anak yang mengalami permasalahan dalam perkembangan kognitif dalam kemampuan berpikir simbolik. Hal ini terlihat dalam proses pembelajaran yang peneliti amati pada pra penelitian, anak belum mampu menyebutkan lambang bilangan, anak terlihat bingung dalam mencocokkan bilangan dengan lambang bilangan, anak belum mampu mengenal nya

Proses pembelajaran dalam meningkatkan kemampuan berpikir simbolik anak dilakukan tanpa menggunakan alat permainan edukatif yang bervariasi, aktivitas pembelajaran dilakukan hanya berfokus pada buku majalah dan lembar kerja siswa sehingga membuat anak jenuh dan kurang kreatif dalam memecahkan suatu masalah. Strategi pembelajaran yang dilakukan 


\section{JURNAL GERIA}

ISSN : XXXX-XXXX (Print) XXXX-XXXX (Online)

Vol.1 | No.1 | Januari 2018

selama ini di TK Sandhy Putra Telkom Dayeuhkolot Kabupaten Bandung hanya berpusat pada guru (teacher center), Strategi pembelajaran seperti ini menyebabkan anak mudah menyerah, anak sering meniru temannya untuk menyelesaikan masalahnya, mudah merasa bosan ketika mengalami kesulitan dalam belajar, dan anak cenderung memilih meminta tolong kepada guru untuk memecahkan masalah yang dihadapinya.

Berdasarkan uraian di atas, peneliti merasa perlu melakukan upaya dalam meningkatkan perkembangan kognitif dalam hal meningkatkan kemampuan berpikir simbolik dengan memberikan aktivitas belajar dengan metode bermain menggunakan alat permainan edukatif puzzle stick es krim. Aktivitas pembelajaran dengan menggunakan alat permainan edukatif puzzle stick es krim dapat mempengaruhi kemampuan berpikir simbolik pada anak. Alat permainan edukatif puzzle stick es krim merupakan media gambar yang termasuk ke dalam media visual, karena dapat dicerna melalui indera penglihatan.

Puzzle stick es krim merupakan alat permainan edukatif dengan cara mengurutkan lambang bilangan pada kepingan stick es krim menjadi gambar utuh. Pembelajaran dengan alat permainan edukatif puzzle stick es krim dapat melatih intelegensi dalam memecahkan masalah, anak akan dilatih untuk berpikir dan aktif di kelas. Aktivitas penggunaan media pembelajaran dengan menggunakan alat permainan edukatif puzzle stick es krim juga melibatkan koordinasi mata dan tangan, anak dapat berekplorasi menurut kemampuannya. Penggunaan media pembelajaran puzzle stick es krim akan melatih anak untuk melatih daya ingat, belajar seraya bermain yang menyenangkan, mengenal berbagai bentuk, berbagai gambar dan warna, mengenal lambang bilangan, mengenal huruf vokal dan huruf konsonan dan dapat melatih daya pikir anak dalam penyusunan kepingan puzzle stick es krim.

Penggunaan alat permainan edukatif puzzle stick es krim akan melatih anak untuk berpikir secara aktif dan mengikuti pembelajaran di kelas dengan kreatif dan lebih bersemangat sehingga proses pembelajaran akan lebih kondusif dan menyenangkan. Alat permainan edukatif puzzle stick es krim ini juga sangat efisien, selain bahan yang diperlukan mudah di dapat, harga yang terjangkau, juga dapat di gunakan di semua tema pembelajaran di sekolah, guru hanya perlu menyesuaikan gambar puzzle yang diperlukan dengan tema pembelajaran yang sedang berlangsung.

Dengan penggunaan alat permainan edukatif puzzle stick es krim tersebut diharapkan aspek perkembangan kognitif dalam hal kemampuan berpikir simbolik anak dapat berkembang dengan optimal dan mampu mempersiapkan anak didik untuk masuk ke jenjang pendidikan selanjutnya. Salah satu aspek yang harus dimiliki pada diri anak adalah aspek perkembangan kognitif. Lingkup perkembangan kognitif yang harus

\section{METODOLOGI}

Penelitian ini menggunakan penelitian kuantitatif, dengan jenis penelitian eksperimen. Sugiyono (2017: 72) mengatakan "metode penelitian eksperimen dapat diartikan sebagai metode penelitian yang digunakan untuk mencari pengaruh perlakuan tertentu terhadap yang lain dalam kondisi yang terkendalikan". 
Desain penelitian yang akan digunakan dalam penelitian ini yaitu desain quasi eksperimen dengan menggunakan kelompok kontrol nonekuivalen (the nonequivalent control group design). Penelitian kuasi eksperimen (quasi experiment) atau disebut juga kuasi percobaan walaupun pada dasarnya sama dengan penelitian eksperimen murni tetapi ada perbedaan dalam beberapa hal. Tujuan penelitian ini adalah sama yaitu untuk menentukan sebab dan akibat serta adanya manipulasi langsung pada kondisi yang diinginkan, sedangkan yang membedakannya adalah dalam kuasi eksperimen tidak ada sistem acak atau random pada subjeknya.

Bentuk desain penelitian yang dipakai adalah Nonequivalent Group Pretest Posttest Design. Desain ini hampir sama dengan two-pretest-posttest design, pada desain penelitian ada dua penilaian yaitu pretest (tahap pengukuran awal) dan posttest (tahap pengukuran akhir) sehingga dapat membandingkan hasil yang diperoleh sebelum diberi perlakuan dan sesudah diberi perlakuan.

\section{HASIL DAN PEMBAHASAN Hasil}

Populasi dan Sampel dalam penelitian ini adalah anak kelompok B yang menjadi kelas Experimen kelompok B1 dan kelas kontrol Kelompok B2.

Tabel 1

Sampel Penelitian

\begin{tabular}{|c|c|c|c|c|}
\hline No & Kelas & L & P & Jml \\
\hline 1 & B1 & 2 & 10 & 12 \\
\hline 2 & B2 & 6 & 5 & 11 \\
\hline & Jml & 8 & 15 & 23 \\
\hline
\end{tabular}

Hasil penelitian Penerapan Metode Bermain Puzzle Stick Es Krim Anak Usia Dini Pada Kelompok B Untuk
Meningkatkan Kemampuan Berpikir Simbolik. Penerapan metode eksperimen, terlebih dahulu dilakukan pretest yaitu dengan observasi dengan hasil yang telah didapat menunjukkan bahwa sebelum penerapan metode eksperimen kemampuan berpikir simbolik anak usia dini pada kelompok $\mathrm{B}$ terbilang masih rendah. Adapun hasil yang diperoleh sebagai berikut :

Tabel 2

Deskripsi Data Kemampuan Berpikir Simbolik

\begin{tabular}{|c|c|c|c|c|c|}
\hline $\begin{array}{l}\text { Variab } \\
\text { el }\end{array}$ & & \multicolumn{2}{|c|}{$\begin{array}{l}\text { Kelas } \\
\text { Eksperimen }\end{array}$} & \multicolumn{2}{|c|}{$\begin{array}{l}\text { Kelas } \\
\text { Kontrol }\end{array}$} \\
\hline \multirow{6}{*}{$\begin{array}{l}\text { Kema } \\
\text { mpuan } \\
\text { Berpiki } \\
\text { r } \\
\text { Simbol } \\
\text { ik }\end{array}$} & & $\begin{array}{c}\text { Pret } \\
\text { es }\end{array}$ & $\begin{array}{c}\text { Post } \\
\text { es }\end{array}$ & $\begin{array}{c}\text { Pret } \\
\text { es }\end{array}$ & $\begin{array}{c}\text { Post } \\
\text { es }\end{array}$ \\
\hline & $\mathrm{N}$ & 12 & 12 & 11 & 11 \\
\hline & $\begin{array}{l}\text { Nilai } \\
\text { Max }\end{array}$ & 32 & 32 & 31 & 32 \\
\hline & $\begin{array}{l}\text { Nilai } \\
\text { Min }\end{array}$ & 25 & 25 & 24 & 24 \\
\hline & $\begin{array}{l}\text { Rata- } \\
\text { rata }\end{array}$ & $\begin{array}{c}27.5 \\
8\end{array}$ & $\begin{array}{c}29.2 \\
5\end{array}$ & $\begin{array}{c}27.6 \\
4\end{array}$ & $\begin{array}{c}26.9 \\
1\end{array}$ \\
\hline & StDev & $\begin{array}{c}2.02 \\
1\end{array}$ & $\begin{array}{c}2.76 \\
8\end{array}$ & $\begin{array}{c}2.46 \\
1\end{array}$ & $\begin{array}{c}2.66 \\
3\end{array}$ \\
\hline
\end{tabular}

Skor Maksimal Ideal Kemampuan Berpikir Simbolik $=10$.

Pada Tabel 1 diperoleh rata-rata tes kemampuan awal untuk kelas eksperimen dan kelas kontrol berbeda sebesar 0,06. Simpangan baku kemampuan awal kelas eksperimen lebih kecil dibandingkan kelas kontrol, sehingga kelas eksperimen lebih menyebar.

Pada tabel tersebut juga terlihat ratarata postes kelas eksperimen dan kelas kontrol berbeda sebesar 2, 3, 4. Pada kelas eksperimen mempunyai simpangan baku lebih besar dibandingkan kelas kontrol. Dapat dilihat bahwa kelas eksperimen memiliki rata-rata kemampuan berpikir simbolik yang lebih tinggi dan penyebarannya lebih besar dibandingkan kelas kontrol. 


\section{JURNAL GERIA}

ISSN : XXXX-XXXX (Print) XXXX-XXXX (Online)

Vol.1 | No.1 | Januari 2018

Dapat disimpulkan bahwa sesudah diberikan perlakuan Penerapan Metode Bermain Puzzle Stick Es Krim Anak Usia Dini Pada Kelompok B Untuk Meningkatkan Kemampuan Berpikir Simbolik telah menunjukkan hasil yang lebih baik dari sebelum diberikan perlakuan bermain puzzle Stick Es Krim. Hal ini menunjukan bahwa penelitian yang dilakukan mengalami peningkatan pada kemampuan berpikir simbolik anak usia dini melalui penerapan metode bermain puzzle stick es krim di kelompok B. Hasil penelitian menunjukkan bahwa kontribusi langsung, penerapan metode bermain puzzle stick es krim pada rata-rata nilai yang diperoleh anak sebelum diberi perlakuan dari rata-rata dari 27,58 menjadi 29,25. Hasil tersebut menjadi bukti empiris adanya pengaruh penerapan metode bermain puzzle stick es krim terhadap kemampuan berpikir simbolik anak.

Penerapan metode bermain puzzle dapat mengoptimalkan kemampuan berpikir simbolik pada anak, hal ini terlihat bahwa kemampuan berpikir simbolik pada anak meningkat dengan penggunaan media. Hasil penelitian ini sejalan dengan pendapat Sanan (2010) pada aspek perkembangan kognitif, kompetensi dan hasil belajar yang diharapkan pada anak adalah anak amapu dan memiliki, kemampuan berpikir secara logis, berpikir kritis, dapat memberi alasan, mampu memcahkan masalah dan menemukan sebab akibat dalam memecahkan masalah yang dihadapi.

\section{KESIMPULAN}

Kemampuan berpikir simbolik anak usia dini kelompok B yang pembelajarannya menggunakan penerapan metode bermain puzzle stick es krim lebih baik dari pada yang pembelajarannya menggunakan pembelajaran sebelumnya.

\section{DAFTAR PUSTAKA}

Fadlillah, M. (2017). Buku Ajar Bermain \& Permainan Anak Usia Dini. Jakarta : Kencana.

Hardiyanti, Leni. dkk (Jurnal of Leni Hardiyanti. "Penggunaan Media dan Kemampuan Berpikir Simbolik Anak Usia Dini". FKIP Universitas Lampung). Tersedia di http://jurnal.fkip.unila.ac.id > index php $>$ PAUD $>$ article $>$ download di akses pada 28 Agustus 2019.

Latif. M., Zukhairina,. \& Zubaidah.R,. Afandi, M. (2013). Orientasi Baru Pendidikan Anak Usia Dini. Jakarta: Prenadamedia Group.

Peraturan Menteri Pendidikan dan Kebudayaan Republik Indonesia No 137 Tahun 2014 tentang Standar Nasional Pendidikan Anak Usia Dini.

Sugiyono. (2017). Metode Penelitian Kuantitatif, Kualitatif dan R\&D. Bandung: Alfabeta,CV. 